\title{
JURNAL ILMIAH \\ HUBUNGAN KOMUNIKASI TERAPEUTIK DAN POLA MAKAN DENGAN KEJADIAN GASTRITIS DI PUSKESMAS UJUNG KARANG BENGKULU TENGAH
}

\author{
${\text { Fatsiwi Nunik Andari }{ }^{*} \text {, Yuni Yulianda }}^{2}$ \\ 1,2Program Studi Ilmu Keperawatan, Universitas Muhammadiyah Bengkulu \\ Email: fatsiwiandari@umb.ac.id
}

\begin{abstract}
ABSTRAK
Gastritis adalah salah satu penyakit yang perlu diwaspadai. Gastritis yang dibiarkan terus menerus akan berdampak pada terjadinya perdarahan pada saluran cerna, ulkus, perforasi dan anemia. Tujuan penelitian ini untuk mengetahui hubungan komunikasi terapeutik perawat dan pola makan dengan kejadian gastritis pada pasien di Puskesmas Ujung Karang Bengkulu Tengah. Penelitian ini merupakan penelitian kuantitatif dengan menggunakan desain case control. Jumlah sampel yang diambil dengan tehnik random sampling adalah 140 pasien, dimana 70 diantaranya merupakan kelompok kasus dan 70 lainnya merupakan kelompok kontrol. Hasil penelitian ini menunjukkan bahwa 60,7\% responden merasa komunikasi terapeutik yang diterima sudah baik dan 39,3\% responden masih kurang. Berdasarkan frekuensi makan pasien, 62,1\% memiliki frekuensi makan yang teratur sedangkan $37,9 \%$ memiliki frekuensi makan yang tidak teratur. Berdasarkan jenis makanan yang dikonsumsi, $41,4 \%$ responden mengkonsumsi makanan yang berisiko terhadap terjadinya gastritis, sedangkan $58,6 \%$ responden mengkonsumsi jenis makanan yang tidak berisiko. Berdasarkan uji statistik chi-square, dapat disimpulkan bahwa terdapat hubungan yang signifikan antara komunikasi terapeutik dan pola makan (frekuensi makan dan jenis makanan yang dikonsumsi) dengan kejadian gastritis pasien di Puskesmas Ujung Karang Bengkulu Tengah. Berdasarkan nilai koefisien kontingensi, pola makan (frekuensi makan dan jenis makanan yang dikonsumsi) derajat hubungan kategori sedang dengan kejadian gastritis, sedangkan komunikasi teapeutik memiliki derajat hubungan kategori lemah dengan kejadian gastritis.
\end{abstract}

Kata Kunci: Gastritis, Komunikasi Terapeutik, Pola Makan

\section{ABSTRACT}

Gastritis is one of the diseases that need more attention. Uncaring gastritis would affect the occurrence of bleeding in the gastrointestinal tract, ulcers, perforation, and anemia. The purpose of this study was to determine the relationship between therapeutic communication and dietary habits with the incidence of gastritis in the Public Health Centre of Ujung Karang, Bengkulu Tengah. This research was a quantitative study with a case-control design. The total sample was 140 patients that were divided into two groups: 70 respondents were in the case group and 70 respondents were in the control group. The results of this study indicate that $60,7 \%$ of respondents received a good communication therapeutic and 39,3\% of respondents stated the communication therapeutic was poor. Based on eating habits, 62,1\% had a regular diet on the eating frequency and 37,9\% was not. For the type of food consumed by the respondents, 41,4\% of respondents had consumed unhealthy food. Based on the chi-square statistical test, there was a significant correlation between therapeutic communication and eating habits with the incidence of gastritis. 
Keywords: eating habits, gastritis, therapeutic communication

\section{PENDAHULUAN}

Seiring dengan
berkembangnya zaman,
penyakit terus mengancam
besehatan
manusia yang muncul dari gaya hidup
manusia itu sendiri dan penularan bakteri. Salah satu penyakit yang perlu diwaspadai adalah gastritis (Shalahuddin dan Rosidin, 2018). Gastritis merupakan peradangan pada mukosa lambung yang disebabkan oleh suatu iritasi atau infeksi. Gastritis juga merupakan tanda pertama terjadinya infeksi sistemik lambung (Smeltzer \& Bare, 2013). Gastritis yang dibiarkan terus menerus akan berdampak pada terjadinya perdarahan pada saluran cerna, ulkus, perforasi dan anemia (Sipponen and Maaroos, 2015).

Gastritis merupakan salah satu penyakit yang diperhitungkan di tingkat dunia. Menurut World Health Organization (WHO) kasus gastritis di dunia mencapai 1,8-2,1 juta dari jumlah penduduk setiap tahunnya. Menurut WHO angka kejadian gastritis di berbagai daerah di Indonesia cukup tinggi yaitu 40,8 \% dengan prevalensi 274,396 kasus dari jumlah penduduk 238,452,952 jiwa (Wahyuni, Rumpiati, dan Lestariningsih, 2017). Berdasarkan data sepuluh penyakit terbanyak di Kota Bengkulu, penyakit gastritis menempati peringkat ke tiga dengan angka morbiditas yakni 12.856 kasus $(9,9 \%)$, setelah ISPA dan penyakit kulit (Dinkes Kota Bengkulu, 2017).

Insiden penyakit gastritis yang mengalami peningkatan sejak $5-6$ tahun terakhir ini bisa menyerang semua jenis kelamin, pada usia remaja sampai dewasa karena pola makan yang buruk, kebiasaan mengkonsumsi alkohol dan merokok (Shalahuddin dan Rosidin, 2018). Pola makan terdiri dari jenis makanan, frekuensi makan, jadwal makan dan porsi makan. Pola makan yang buruk seperti jadwal makan yang tidak teratur, mengkonsumsi makanan yang memiliki nilai gizi rendah dan meningkatkan produksi asam lambung, serta jumlah makanan yang terlalu banyak dan juga terlalu sedikit (Hidayah, 2014). Dalam pola makan, frekuensi makan juga perlu diperhatikan. Secara ilmiah makanan diperoleh dalam tubuh melalui alat-alat pencernaan mulai dari mulut sampai usus halus. Lama makanan dalam lambung tergantung sifat dan jenis makanan. Jika rata-rata, umumnya lambung kosong antara 3-4 jam, maka jadwal makan pun harus sesuai dengan kosongnya lambung (Ramali, 2010).

Pola makan yang tidak teratur merupakan hal yang biasa namun kebiasaan ini dapat menyebabkan risiko gastritis sehingga perlu dilakukan upaya pencegahan. Salah satu usaha pencegahan adalah dengan memberikan edukasi melalui komunikasi yang baik atau terapeutik yang dapat dilakukan oleh perawat. Komunikasi terapeutik adalah komunikasi yang dilakukan atau dirancang untuk tujuan terapi, atau dengan kata lain untuk kesembuhan pasien. Seorang terapis dapat membantu klien mengatasi masalah yang dihadapinya melalui komunikasi (Damaiyanti dan Iskandar, 2014).

$$
\text { Menurut Roudhonah }
$$
perawat dapat melakukan komunikasi terapeutik baik secara verbal maupun non verbal. Komunikasi verbal dinilai lebih akurat dan tepat waktu serta memungkinkan tiap individu untuk berespon secara langsung. Meskipun begitu, bahasa isyarat pada komunikasi non verbal dapat menambah arti terhadap pesan verbal yang disampaikan perawat.

$$
\text { Perawat yang memiliki }
$$

keterampilan berkomunikasi secara terapeutik akan mudah menjalin hubungan rasa percaya dengan klien, mencegah terjadinya masalah legal, memberikan kepuasan profesi dalam pelayanan keperawatan dan meningkatkan citra profesi keperawatan. Hal ini didasari bahwa komunikasi 
terapeutik adalah modal dasar intervensi utama perawat yang digunakan untuk membentuk hubungan dengan klien dalam hal pemenuhan kebutuhan (Andriyani, Darmawan dan Hidayati, 2018).

Berdasarkan studi pendahuluan yang sudah dilakukan peneliti sebelumnya menunjukkan bahwa angka kejadian gastritis di Puskesmas Ujung Karang Bengkulu Tengah dalam beberapa tahun ini mengalami peningkatan jumlah kasus. Hasil wawancara terhadap 8 orang penderita gastritis yang diberikan informasi kesehatan melalui edukasi tentang gastritis dengan menggunakan komunikasi terapeutik oleh perawat yang menanganinya saat melakukan pengobatan di Puskesmas Ujung Karang Bengkulu Tengah mengatakan bahwa banyak informasi positif yang didapatkan dari edukasi tentang gastritis yang sudah diberikan sehingga pasien dapat lebih waspada untuk menghindari dampak yang lebih buruk dari gastiritis.

Berdasarkan kondisi di atas maka peneliti tertarik untuk melakukan penelitian tentang "Hubungan komunikasi terapeutik perawat dan pola makan dengan kejadian gastritis pada pasien di Puskesmas Ujung Karang Bengkulu Tengah.

\section{METODE PENELITIAN}

Penelitian ini merupakan penelitian kuantitatif dengan mengunakan desain case control untuk mengetahui hubungan antara variabel independen dan variabel dependen berdasarkan perjalanan waktu secara simultan (Riyanto, 2011). Adapun variabel independen pada penelitian ini adalah komunikasi terapeutik perawat dan pola makan, sedangkan variabel dependen adalah kejadian gastritis.

Penelitian dilakukan di Puskesmas Ujung Karang Bengkulu Tengah dengan jumlah populasi adalah semua pasien gastritis yang berkunjung ke Puskesmas Ujung Karang selama 1 bulan (April Mei 2017) yang berjumlah 239 pasien. Penelitian ini menggunakan desain case control dengan tehnik pengambilan sampel menggunakan random sampling, sehingga jumlah sampel yang digunakan pada penelitian ini adalah 70 pasien untuk sampel kasus dan 70 pasien untuk sampel kontrol sehingga total sampel pada penelitian ini adalah sebanyak 140 orang responden.

Data primer dalam penelitian ini diperoleh secara langsung dari responden dengan cara mengisi kuesioner penelitian yang telah dibuat sesuai dengan aspek diukur. Sedangkan, data sekunder dalam penelitian ini berupa data pasien yang berkunjung ke Puskesmas Ujung Karang yang diperoleh dari medical record Puskesmas Ujung Karang Bengkulu Tengah.

Proses pelaksanaan penelitian diawali dari pengurusan surat izin penelitian mulai dari Dinas Penanaman Modal dan Pelayanan terpadu Satu Pintu Kabupaten Bengkulu Tengah, Dinas Kesehatan Kabupaten Bengkulu Tengah, hingga ke Puskesmas Ujung Karang Bengkulu Tengah. Setelah itu peneliti melakukan informed consent kepada responden penelitian. Kemudian peneliti memberikan kuesioner penelitian kepada responden. Data hasil pengisian kuesioner responden kemudian diolah melalui proses editing, koding, entry, dan clearing data. Teknik analisis data yang digunakan meliputi analisis univariat dan bivariat.

Analisis univariat dilakukan untuk mengetahui gambaran distribusi frekuensi variabel yang diteliti baik variabel independen (komunikasi teraupetik perawat dan pola makan) maupun variable dependen (kejadian gastritis) dengan menggunakan persentase (\%) (Nursalam, 2013). Analisis bivariat bertujuan untuk melihat hubungan 
komunikasi terapeutik perawat dan pola makan dengan kejadian gastritis. Data dianalisa dengan menggunakan uji $C h i$ Square $\left(\mathrm{X}^{2}\right)$ dan untuk mengetahui keeratan hubungan digunakan uji statistik Contingency Coefficient

\section{HASIL PENELITIAN}

Analisis Univariat

Tabel 1. Distribusi Frekuensi Komunikasi

Terapeutik Perawat di Puskesmas

Ujung Karang Bengkulu Tengah

\begin{tabular}{llll}
\hline $\begin{array}{l}\text { No } \\
\text { Terapeutik }\end{array}$ & Frekuensi \\
\hline 1 & Kurang & 55 & (\%) \\
2 & Baik & 85 & 60.7 \\
Jumlah & 140 & 100 \\
\hline
\end{tabular}

Berdasarkan Tabel 1. di atas dapat diketahui bahwa dari 140 responden, terdapat 85 responden $(60,7 \%)$ merasa komunikasi terapeutik perawat kepada mereka sudah baik, sedangkan 55 responden $(39,3 \%)$ menilai bahwa komunikasi terapuetik yang perawat berikan masih kurang, karena itu masih perlu untuk ditingkatkan lagi.

Tabel 2. Distribusi Frekuensi Makan Pasien di Puskesmas Ujung Karang Bengkulu Tengah

\begin{tabular}{llll}
\hline $\begin{array}{l}\text { No } \\
\text { Makan } \\
\text { Makuensi }\end{array}$ & Frekuensi $(\%)$ \\
\hline 1 & Berisiko & 53 & 37.9 \\
2 & Teratur & 87 & 62.1 \\
\hline & Jumlah & 140 & 100 \\
\hline
\end{tabular}

Berdasarkan Tabel 2. di atas dapat diketahui bahwa dari 140 responden, terdapat 87 responden $(62,1 \%)$ memiliki pola makan yang teratur, sedangkan 53 responden $(37,9 \%)$ memiliki pola makan yang berisiko. Pola makan responden dikategorikan teratur jika makan besar minimal $3 \mathrm{x}$ sehari, sedangkan jika makan besar < 3 x sehari, maka pola makan responden dikategorikan berisiko.

Tabel 3. Distribusi Frekuensi Jenis Makanan Yang Dikonsumsi di Puskesmas Ujung Karang Bengkulu Tengah

\begin{tabular}{llll}
\hline $\begin{array}{l}\text { No Jenis } \\
\text { Makanan }\end{array}$ & Frekuensi & $(\boldsymbol{\%})$ \\
\hline 1 & Berisiko & 58 & 41.4 \\
2 & $\begin{array}{l}\text { Tidak } \\
\text { berisiko }\end{array}$ & 82 & 58.6 \\
\hline & Jumlah & 140 & 100 \\
\hline
\end{tabular}

Berdasarkan Tabel 3. di atas dapat diketahui bahwa dari 140 responden, terdapat 82 responden $(58,6 \%)$ mengkonsumsi jenis makanan yang tidak berisiko, sedangkan 58 responden $(41,4 \%)$ mengkonsumsi jenis makanan yang berisiko. Jenis makanan berisiko yang dikonsumsi responden dalam penelitian ini adalah makanan pedas, makanan asam, dan mie instan. Jenis makanan berisiko ini dapat menyebabkan gastritis jika dikonsumsi secara berlebihan dan dalam jumlah yang banyak.

\section{Analisis Bivariat}


Tabel 4. Hubungan Komunikasi Terapeutik Perawat Dengan Kejadian Gastritis di Puskesmas Ujung Karang Bengkulu Tengah

\begin{tabular}{lllllll}
\hline Komunikasi & \multicolumn{2}{l}{ Kejadian Gastritis } & \multirow{2}{*}{ Total } & \multirow{2}{*}{ P } & \multirow{2}{*}{ C } \\
\cline { 2 - 5 } Terapeutik & Ya & Tidak & & & \\
\hline Kurang Baik & 34 & 21 & 55 & & & \\
Baik & 36 & 49 & 85 & 4.31 & 0.038 & 0.187 \\
Total & 70 & 70 & 140 & & & \\
\hline
\end{tabular}

Berdasarkan Tabel 4. di atas dapat diketahui bahwa hasil perhitungan tabulasi silang antara komunikasi terapeutik perawat dengan kejadian gatritis di Puskesmas Ujung Karang Bengkulu Tengah yaitu dari 55 responden yang menilai bahwa komunikasi terapeutik yang mereka terima kurang baik, 34 diantaranya merupakan penderita gastritis sedangkan 21 responden lainnya bukan penderita gastritis. Sementara itu, dari 85 responden yang menilai bahwa komunikasi terapeutik yang mereka terima adalah baik, 36 orang diantaranya merupakan penderita gastritis sedangkan 49 responden lainnya bukan merupakan penderita gastritis.

Hasil penelitian juga menunjukkan nilai chi-square $(\chi 2)$ sebesar 4,31 dan nilai $\mathrm{p}=0,038$. Karena nilai $\mathrm{p}=0,038<$
0,05 maka hipotesis nol ditolak, hipotesis alternatif diterima, sehingga dapat disimpulkan bahwa ada hubungan yang signifikan antara komunikasi terapeutik perawat dengan kejadian gastritis.

Derajat hubungan antara komunikasi terapeutik perawat dengan kejadian gastritis yang diukur dari nilai Koefisien kontingensi (C) dengan nilai pembanding, yaitu C_max=0,707. Pada penelitian ini diperoleh nilai $\mathrm{C}=0,187$. Karena nilai $\mathrm{C}=0,187$ cukup jauh dengan nilai C_max $=0,707$, maka dapat disimpulkan bahwa derajat hubungan komunikasi terapeutik dengan kejadian gastritis dalam kategori lemah.

Tabel 5. Hubungan Frekuensi Makan Dengan Kejadian Gastritis di Puskesmas Ujung Karang Bengkulu Tengah

\begin{tabular}{lllllll}
\hline Frekuensi Makan & \multicolumn{2}{l}{ Kejadian Gastritis } & \multirow{2}{*}{ Total } & \multirow{2}{*}{ P } & \multirow{2}{*}{ C } \\
\cline { 2 - 6 } & Ya & Tidak & & & & \\
\hline Berisiko & 43 & 10 & 53 & & & \\
Teratur & 27 & 60 & 87 & 31.091 & 0.000 & 0.437 \\
Total & 70 & 70 & 140 & & & \\
\hline
\end{tabular}

Berdasarkan Tabel 5. di atas dapat diketahui bahwa hasil perhitungan tabulasi silang antara frekuensi makan dengan kejadian gatritis di Puskesmas Ujung Karang Bengkulu Tengah yaitu dari 53 responden yang memiliki frekuensi makan yang berisiko, 43 diantaranya mengalami gastritis sedangkan 10 responden lainnya tidak mengalami gastritis. Berikutnya dari 87 responden yang frekuensi makannya teratur, 27 diantaranya mengalami gastritis dan 60 responden lainnya tidak mengalami gastritis.

Hasil uji hubungan antara frekuensi makan dengan kejadian gastritis, diperoleh nilai chi-square $\left(\chi^{2}\right)=31,091$ dan nilai $\mathrm{p}=0,000$. Karena nilai $\mathrm{p}=$ $0,000<0,05$ maka hipotesis nol ditolak, hipotesis alternatif diterima sehingga dapat disimpulkan bahwa ada hubungan 
yang signifikan antara frekuensi makan dengan kejadian gastritis.

Derajat hubungan antara pola makan dengan kejadian gastritis diperoleh nilai
$\mathrm{C}=0,437$. Karena nilai $\mathrm{C}=0,437$ cukup dekat dengan nilai $C_{\max }=0,707$, maka dapat disimpukan bahwa derajat hubungan pola makan dengan kejadian gastritis dalam kategori sedang

Tabel 6. Hubungan Jenis Makanan Yang Dikonsumsi Dengan Kejadian Gastritis di Puskesmas Ujung Karang Bengkulu Tengah

\begin{tabular}{lllllll}
\hline Jenis Makanan & \multicolumn{2}{l}{ Kejadian Gastritis } & \multirow{2}{*}{ Total } & \multirow{2}{*}{ P } & \multirow{2}{*}{ C } \\
\cline { 2 - 5 } & Ya & Tidak & & & \\
\hline Berisiko & 45 & 13 & 58 & & & \\
Tidak Berisiko & 25 & 57 & 82 & 28.2 & 0.000 & 0.421 \\
Total & 70 & 70 & 140 & & & \\
\hline
\end{tabular}

Berdasarkan Tabel 6. di atas dapat diketahui bahwa hasil perhitungan tabulasi silang antara jenis makanan yang dikonsumsi dengan kejadian gastritis di Puskesmas Ujung Karang Bengkulu Tengah yaitu dari 58 responden yang mengkonsumsi makanan yang berisiko, 45 diantaranya mengalami gastritis sedangkan 13 responden lainnya tidak mengalami gastritis. Berikutnya dari 82 responden yang mengkonsumsi makanan yang tidak berisiko, 25 diantaranya mengalami gastritis sedangkan 57 responden lainnya tidak mengalami gastritis.

Hasil uji hubungan antara frekuensi makan dengan kejadian gastritis, diperoleh nilai chi-square $\left(\chi^{2}\right)=28,28$ dan nilai $\mathrm{p}=0,000$. Karena nilai $\mathrm{p}=$ $0,000<0,05$ maka hipotesis nol ditolak, hipotesis alternatif diterima sehingga dapat disimpulkan bahwa ada hubungan yang signifikan antara jenis makanan yang dikonsumsi dengan kejadian gastritis.

Untuk derajat hubungan antara pola makan dengan kejadian gastritis diperoleh nilai $\mathrm{C}=0,437$. Karena nilai $\mathrm{C}$ $=0,437$ cukup dekat dengan nilai $C_{\max }=$ 0,707, maka dapat disimpukan bahwa derajat hubungan pola makan dengan kejadian gastritis dalam kategori sedang.
PEMBAHASAN

Komunikasi Terapeutik Perawat Di Puskesmas Ujung Karang Bengkulu Tengah

Hasil penelitian menunjukkan bahwa dari 140 responden, terdapat 55 responden $(39,3 \%)$ yang menilai bahwa komunikasi terapeutik perawat yang diterimanya kurang baik, sedangkan 85 responden $(60,7 \%)$ menilai bahwa komunikasi terapeutik yang diterimanya sudah baik. Berdasarkan hasil penelitian ini, terlihat bahwa sebagaian besar perawat yang bertugas di Puskesmas Ujung Karang Bengkulu Tengah sudah mampu menerapkan teknik komunikasi terapeutik yang baik.

Menurut Priyanto (2009), komunikasi terapeutik merupakan komunikasi professional yang mengarah pada tujuan untuk penyembuhan pasien yang dilakukan oleh perawat atau tenaga kesehatan lainnya. Komunikasi terapeutik tidak dapat berlangsung dengan sendirinya, tetapi harus direncanakan, dipertimbangkan, dan dilaksanakan secara professional.

Komunikasi terapeutik yang dilakukan perawat diharapkan dapat memberikan pengaruh positif pada kesadaran diri pasien terhadap risiko dan faktor pemicu gastritis. Komunikasi 
terapeutik yang disampaikan dengan cara yang baik akan mudah diterima oleh pasien dan dapat diterapkan dalam kehidupan sehari-hari dalam mencegah kekambuhan gastritis.. Untuk dapat menerapkan komunikasi dengan efektif, perawat harus mempunyai keterampilan yang memadai dan memahami dirinya dengan baik (Sinaulan, 2016).

Banyak faktor yang menyebabkan penilaian yang kurang baik terhadap komunikasi terapeutik yang diterima oleh pasien. Sumber penyebab yang pertama dapat bersumber dari perawat yang memberikan, misalnya dalam penelitian ini ada beberapa pasien yang menilai bahwa perawat yang melayaninya kurang ramah dan tidak menyebut nama pasien. Sumber kedua adalah berasal dari pasien, misalnya ada pasien yang tidak bersabar untuk mengantri padahal pada saat berkunjung suasana puskesmas sedang ramai pengunjung. Oleh karena itu, perlu kajian yang lebih dalam tentang penyebab ada pasien yang merasa komunikasi terapeutik yang diterimanya masih kurang baik.

\section{Pola Makan (Frekuensi Makan dan Jenis Makanan Yang Di Konsumsi Pasien di Puskesmas Ujung Karang Bengkulu Tengah}

Hasil penelitian menunjukkan bahwa bahwa dari 140 responden, 53 responden $(37,9 \%)$ merupakan kelompok dengan frekuensi makan yang berisiko, sedangkan 87 responden $(62,1 \%)$ memiliki frekuensi makan yang teratur. Kemudian terdapat 58 responden $(41,4 \%)$ memiliki kebiasaan mengkonsumsi jenis makanan yang berisiko, sedangkan 82 responden $(58,6 \%)$ mengkonsumsi jenis makanan yang tidak berisiko terhadap timbulnya gastritis.

Hasil penelitian ini menggambarkan bahwa sebagian besar pasien memiliki kesadaran akan pentingnya menjaga pola makan baik dalam hal frekuensi makan maupun jenis makanan yang dikonsumsi setiap harinya. Pola makan yang teratur sangat penting bagi kesehatan tubuh kita. Pola makan yang tidak diatur dengan baik akan menimbulkan kekambuhan pada penderita (Sulastri, 2012). Pola makan yang baik mencegah terjadinya gastritis (Wahyu, Supono, dan Hidayah, 2015)

Hasil penelitian ini sejalan dengan penelitian Gustin (2011), yang menyatakan bahwa sebagian besar responden $(53 \%)$ peduli dengan pola makannya untuk menghindari terjadinya gastritis. Hasil penelitian ini juga didukung oleh hasil penelitian Murjayanah (2011) sebagian besar pasien $(57,1 \%)$ tidak mengkonsumsi jenis makanan yang berisiko, yang dapat merangsang asam lanmbung sehingga memicu tejadinya gastritis.

Pada kasus gastritis biasanya diawali dari pola makan yang tidak teratur, misalnya sering terlambat makan 2-3 jam sehingga asam lambung yang diproduksi menjadi semakin banyak. Produksi asam lambung yang meningkat menyebabkan lambung menjadi sensitive. Produksi asam lambung yang berlebihan dapat menyebabkan terjadinya gesekan pada lambung, sehingga timbul rasa nyeri di sekitar epigastrum. Gesekan akan lebih parah apabila lambung kosong akibat makan tidak teratur, yang dapat mengiritasi dinding mukosa lambung dan dapat berlanjut menjadi tukak peptic (Suparyanto, 2012).

\section{Hubungan Komunikasi Terapeutik dan Pola Makan dengan Kejadian Gastritis di Puskesmas Ujung Karang Bengkulu Tengah}

Hasil penelitian didapatkan bahwa dari 140 responden, $60,7 \%$ responden menilai komunikasi terapeutik yang mereka terima sudah baik, sedangkan $39,3 \%$ responden menilai bahwa komunikasi terapeutik yang diterima 
masih kurang baik, sehingga masih perlu untuk ditingkatkan.

Berdasarkan hasil uji hubungan antara komunikasi terapeutik dengan kejadian gastritis di wilayah kerja Puskesmas Ujung Karang, diperoleh kesimpulan bahwa ada hubungan yang signifikan antara komunikasi terapeutik dengan kejadian gastritis. Namun derajat hubungan keduanya tergolong lemah. Hal ini dapat dilihat dari besaran nilai koefisien kontingensi sebesar 0,187 yang masih cukup jauh dengan nilai pembandingnya $C_{\max }=0,707$.

Pada dasarnya komunikasi terapeutik merupakan komunikasi professional yang mengarah pada tujuan yaitu penyembuhan pasien dan pencegahan penyakit (Siti, 2010). Orang yang mempunyai riwayat penyakit gastritis dan tidak disembuhkan, maka penyakit gastritis menjadi kronik dan susah untuk disembuhkan (Andri, 2011). Oleh karena itu, komunikasi terapeutik memiliki peranan yang penting dalam proses penyembuhan gastritis maupun pencegahannya.

Agar tercapai pelaksanaan komunikasi terapeutik yang efektif, maka dalam pelayanan keperawatan hendaknya diterapkan pula sikap-sikap terapeutik, seperti memberikan motivasi terhadap perilaku yang kurang tepat, bukan mengajari pasien. Selain itu perawat dapat menggunakan perasaan dan pikiran pasien sebagai kekuatan untuk merubah perilaku pasien serta perawat menunjukkan sikap memberikan kesempatan keada pasien untuk mengungkapkan tanggapannya dalam interaksi yang terjadi. (Andriyani, Darmawan dan Hidayati, 2018).

Pada penelitian ini juga diperoleh bahwa dari 140 responden yang diteliti, $62,1 \%$ diantaranya memiliki pola makan yang teratur atau baik, sedangkan 37,9\% lainnya memiliki pola makan yang berisiko mengalami gastritis serta terdapat 58 responden $(41,4 \%)$ memiliki kebiasaan mengkonsumsi jenis makanan yang berisiko dan 82 responden $(58,6 \%)$ mengkonsumsi jenis makanan yang tidak berisiko. Berdasarkan hasil uji hubungan antara pola makan dengan kejadian gastritis diperoleh kesimpulan bahwa ada hubungan signifikan antara pola makan dengan kejadian gastritis. Derajat hubungan keduanya tergolong sedang. Hal ini dilihat dari besaran nilai koefisien kontingensi sebesar 0,437 dan 0,421 yang cukup dekat dengan nilai $C_{\max }=0,707$. Derajat hubungan sedang ini menggambarkan bahwa pola makan yang tidak baik merupakan salah satu faktor pemicu terjadinya gastritis.

Berdasarkan tabulasi silang, dari 70 responden yang terkena gastritis 43 diantaranya memang memiliki frekuensi makan yang berisiko sehingga menyebabkan terjadinya gastritis, sedangkan 27 lainnya memiliki frekuensi makan yang teratur namun masih tetap mengalami gastritis. Begitu juga hasil tabulasi silang pada jenis makanan yang dikonsumsi dimana dari 70 responden yang menderita gastritis, 45 diantaranya mengkonsumsi jenis makanan yang berisiko dan 25 lainnya tidak.

Hasil penelitian ini sejalan dengan beberapa penelitian sebelumnya, seperti penelitian yang dilakukan oleh Yunita (2010) bahwa, kejadian gastritis dipengaruhi oleh keteraturan dan frekuensi makan. Penelitian lainnya yang dilakukan oleh Muhith dan Siyoto (2016) juga menyatakan bahwa pola makan berpengaruh terhadap kejadian gastritis. Hal ini dikarenakan faktor pekerjaan sehingga menyebabkan responden makan tidak teratur. Selain itu adanya kebiasaan responden yang merasa sudah cukup kenyang dengan merokok walau tidak makan. Atau dengan kata lain responden lebih memilih menunda makan dan lebih memlilih untuk merokok.

Baliwati (2009) dalam Pratiwi (2013) menyatakan bahwa pola makan yang baik dan teratur merupakan salah satu penatalaksanakan gastritis. Selain itu kebiasaan baik ini merupakan langkah 
preventif dalam mencegah terjadinya kekambuhan penyakit gastritis. Dalam penyembuhan gastritis diperlukan pengaturan makanan sebagai upaya untuk memperbaiki sistem pencernaan. Pola makan yang dianjurkan adalah pola makan yang sumbangan energinya berasal dari karbohidrat (60-70\%), protein (15-20\%) dan lemak (20-30\%), ditambah cukup vitamin, mineral dan serat. Pola makan tersebut terbagi dalam 3 periode yaitu sarapan, makan siang dan makan malam. Peranan sarapan tidak boleh diabaikan, karena makanan menentukan kerja tubuh dari pagi hingga siang hari (Megawati, Nosi, dan Syaipuddin, 2014).

Pemilihan jenis makanan dan frekuensi makan yang salah dalam kehidupan sehari-hari merupakan salah satu penyebab kambuhnya gastritis. Mengkonsumsi jenis makanan yang pedas, asam dan siap saji dengan frekuensi yang sering dapat menimbulkan kekambuhan gastritis Semakin tidak teraturnya makan dan mengkonsumsi jenis makanan pedas, asam dan siap saji sangat berpengaruh terhadap kekambuhan gastritis. Motivasi dan kesadaran diri sendiri juga dibutuhkan dalam pemilihan jenis makanan dan frekuensi makan yang baik sehingga kambuhnya gastritis dapat dicegah (Sari dan Indah, 2013).

\section{KESIMPULAN}

Berdasarkan hasil penelitian ini dapat disimpulkan bahwa ada hubungan yang signifikan antara komunikasi terapeutik, pola makan (frekuensi makan dan jenis makanan yang dikonsumsi) dengan kejadian gastritis di Puskesmas Ujung Karang Bengkulu Tengah. Derajat hubungan untuk variabel komunikasi terapeutik tergolong sedang, sedangkan untuk pola makan tergolong lemah.

Bagi Puskesmas Ujung Karang disarankan untuk lebih aktif dalam memberikan informasi kepada masyarakat tentang bahaya gastritis dan pencegahannya melalui promosi kesehatan yang dapat berbentuk promosi langsung maupun berbentuk selebaran. Selain itu pihak Puskesmas Ujung Karang diharapkan dapat meningkatkan komunikasi terapeutik dalam pelayanan keperawatan kepada pasien.

Bagi pasien Puskesmas Ujung Karang diharapkan agar lebih memperhatikan pola makannya yaitu frekuensi makan dan jenis makanan yang dikonsumsi dalam upaya mencegah terjadinya gastritis maupun kekambuhannya kembali. Bagi peneliti selanjutnya dapat dikembangkan lagi dengan menambahkan variabel lain dan modifikasi desain penelitian lainnya.

\section{DAFTAR PUSTAKA}

Andriyani, Darmawan dan Hidayati. (2018). Buku Ajar Komunikasi Dalam Keperawatan. Bandung: PT. Refika Aditama.

Smeltzer \& Bare. (2013). Buku Ajar Keperawatan Medikal Bedah Edisi 8. Jakarta: EGC.

Damaiyanti dan Iskandar. (2014). Asuhan Keperawatan Jiwa. Bandung: PT. Refika Aditama.

Dinkes Kota Bengkulu. (2017). Profil Kesehatan Kota Bengkulu Tahun 2016. Bengkulu: Dinas Kesehatan Kota Bengkulu.

Hidayah. (2014). Kesalahan-kesalahan Pola Makan Pemicu Seabrek Penyakit. Poltekkes Kemenkes Padang.

Megawati, Nosi, dan Syaipuddin. (2014). Beberapa Faktor yang Berhubungan Dengan Kejadian Gastritis Pada Pasien yang Di rawat Di RSUD Labuang Baji Makassar. Jurnal Ilmiah Kesehatan Diagnosis Volume 4 Nomor 1 Tahun 2014 http://www.ejournal.stikesnh.ac.id/in dex.php/jikd/article/view/621 
Muhith, A dan Siyoto, S. (2016). Pengaruh Pola Makan Dan Merokok Terhadap Kejadian Gastritis Pada Lansia. E-Journal Keperawatan Vol.9 No.3 http://journal.poltekkesdepkessby.ac.id/index.php/KEP/article/view $\underline{1326}$

Murjayanah, H. (2011). Faktor-faktor Risiko Yang Berhubungan Dengan Kejadian Gastritis. Universitas Negeri Semarang. Fakultas Ilmu Keolahragaan, Semarang. Skripsi. http://lib.unnes.ac.id/2702/1/3470.pd $\underline{\mathrm{f}}$

Nursalam. (2013). Metodologi Penelitian Ilmu Keperawatan. Jakarta: Salemba Medika.

Pratiwi, W. (2013). Hubungan Pola Makan Dengan Gastritis Pada Remaja Di Pondok Pesantren Daar El-Qolam Gintung, Jayanti, Tangerang. Skripsi. UIN Syarif Hidayatullah Jakarta.

Priyanto, A. (2009). Komunukasi dan Konseling Aplikasi Dalam Sarana Pelayanan Kesehatan Untuk Perawat dan Bidan. Jakarta : Salemba Medika.

Gustin, R. K. (2011). Faktor-Faktor yang Berhubungan Dengan Kejadian Gastritis pada Pasien yang Berobat Jalan Di Puskesmas Gulai Bancah. Kota Bukittinggi. Artikel Penelitian, http://www.academia.edu

Ramali. (2010). Tips Diet Maag. http://nursingbegin.com/tips-diet$\underline{\text { maag }}$

Riyanto, A. (2011). Aplikkasi Metodelogi Penelitian Kesehatan. Yogyakarta: Nuha Medika.

Roudhonah. (2019). Ilmu Komunikasi. Depok: PT Rajagrafindo Persada.
Sari dan Indah. (2013). Hubungan Jenis Makanan Dan Frekuensi Makan Dengan Kekambuhan Gastritis Di Rumah Sakit Wiyung Sejahtera Surabaya.

http://repository.unusa.ac.id/id/eprint $\underline{12049}$

Shalahuddin, I dan Rosidin, U. (2018). Hubungan Pola Makan Dengan Gastritis Pada Remaja Di Sekolah Menengah Kejuruan Ybkp3 Garut. Jurnal kesehatan Bakti Tunas Husada vol.18 No. 1 tahun 2018. https://www.ejurnal.stikesbth.ac.id/in dex.php/P3M_JKBTH/article/view/3 $\underline{03}$

Sinaulan, R. L. (2016). Komunikasi Terapeutik Dalam Perspektif Islam. Jurnal Komunikasi Islam Vol.6 No.01 tahun 2016. http://jki.uinsby.ac.id/index.php/jki/a rticle/view/108/90

Sipponen, P and Maaroos, H. (2015). Chronic Gastritis. Scandinavian journal of gastroenterology, 50 (6). https://pubmed.ncbi.nlm.nih.gov/259 $\underline{01896 /}$

Siti, F. (2010). . Komunikasi Keperawatan Plus materi Komunikasi Terapeutik. Yogyakarta: Medical Book.

Sulastri. (2012). Gambaran Pola Makan Penderita Gastritis Di Wilayah Kerja Puskesmas Kampar Kiri Hulu Kecamatan Kampar Kiri Hulu Kabupaten Kampar Riau. Skripsi. Sumatera: Fakultas Kesehatan Masyarakat USU.

Suparyanto. (2012). Etiologi dan Penanganan Gastritis.

http:// etiologi-dan-penanganangastritis.html.

Wahyu, Supono, dan Hidayah. (2015). ). Pola Makan Sehari-Hari Penderita Gastritis. Jurnal Informasi 
Kesehatan Indonesia (JIKI), volume 1, no. 1, mei 2015: 17-24. Jurnal informasi kesehatan Indonesia, 2015 - academia.edu.

Wahyuni, S. D., Rumpiati, dan Lestariningsih, R. (2017). Hubungan Pola Makan dengan Kejadian Gastritis Pada Remaja. Journal Global Health Science, 2(2), 149154.

jurnal.csdforum.com/index.php/GHS /article/download/100/41\%0A\%0A

Yunita, R. (2010). Hubungan Antara Karakteristik Responden, Kebiasaan Makan dan Minum Serta Pemakaian NSAID dengan Terjadinya Gastritis pada Mahasiswa Kedokteran. Skripsi tidak diterbitkan. Fakultas Kedokteran Universitas Airlangga. Diakses dari www.repository.unair.ac.id 